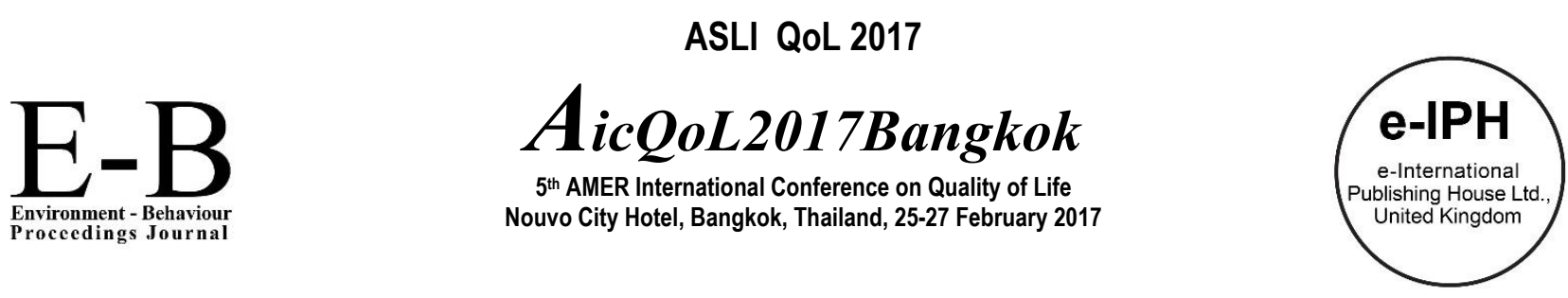

\title{
A Qualitative Study on the Determination of Healthy Cafeteria Practice in Selangor, Malaysia
}

\author{
Nuraini Amirah Salhadi ${ }^{*}$, Mohd Ramadan Ab Hamid ${ }^{1}$, Noor Suzana Osman², Norazmir Md Nor ${ }^{1}$ \\ ${ }^{1}$ Centre of Nutrition and Dietetics, Faculty of Health Sciences, Universiti Teknologi MARA, \\ Selangor Darul Ehsan, Malaysia. \\ ${ }^{2}$ Department of Healthcare Professionals, Faculty of Health and Life Sciences, \\ Management and Science University, \\ Selangor Darul Ehsan, Malaysia.
}

\begin{abstract}
The prevalence of obesity around the world is increasing yearly. Dietary intake, physical inactivity, and sedentary lifestyle are the common causes of obesity. This situation has created an urge to improve a healthy eating environment in the community. Eating outside is more common nowadays especially during working hours. Workers normally will have their meal at the cafeteria. Their dietary intake is directly affected by the availability of food choices at the cafeteria. Thus, a qualitative study was conducted to identify the perceptions of healthy cafeteria among food operators in Selangor, Malaysia. Eleven food handlers at three selected cafeterias were recruited by a convenience sampling based on the inclusion criteria of the study. The respondents consist of three full-time managers, five full-time food handlers, and three full-time cleaners. Semi-structured interviews were conducted with the aid of video and audio recording. The phenomenon of interest was to explore the perceptions, suggestions, challenges and limitation of healthy cafeteria practice among cafeteria operators. The interview transcripts were analysed verbatim based on the objectives and identified themes of the study. Themes include food safety, food handling course, food availability, methods of cooking, foods' hygiene and sanitation. Findings showed that most of the respondents have the similar understanding of healthy cafeteria in which includes healthy menu and clean environment. The respondents also have the knowledge on food safety. The challenges faced by the food handlers were making sure every staff has the correct understanding of healthy foods, using the safe kitchen utensils and financial constraint. Regarding promoting healthy cafeteria environment, the respondents suggested to provide printed educational materials, serve healthy menu selections, organise healthy eating campaign and provide appropriates kitchen utensils. This study revealed that training on food safety and education on healthy food choices are important to provide a healthy eating environment.
\end{abstract}

Keywords: Obesity; Healthy Cafeteria, Food Safety; Healthy Eating.

ISSN: 2398-42870 2017. The Authors. Published for AMER ABRA by e-International Publishing House, Ltd., UK. This is an open access article under the CC BYNC-ND license (http://creativecommons.org/licenses/by-nc-nd/4.0). Peer-review under responsibility of AMER (Association of Malaysian Environment-Behaviour Researchers), ABRA (Association of Behavioural Researchers on Asians) and cE-Bs (Centre for Environment-Behaviour Studies), Faculty of Architecture, Planning \& Surveying, Universiti Teknologi MARA, Malaysia.

\subsection{Introduction}

The prevalence of non-communicable diseases (NCDs) is increasing throughout the years in many developing countries cause by rapid social and economic growth, and it has become a serious health problem (Jan Mohamed et al., 2015). According Majid et al. (2015), the risk factors that can contribute to obesity are genetic, diet intake, physical activity, and the sedentary lifestyle. Mansor \& Harun (2014) and Wolfenden et al., (2015) also supported that besides healthy food intake; regular physical activity also contributes to overall health and fitness. In a study by Strasser (2013) recommended that physical activities must be included in preventing and cure obesity. Also, Kimokoti \& Millen (2011) claimed that nutrition transition could also cause the increasing number of obesity and metabolic syndrome. On the other hand, research by Davey, Allotey, \& Reidpath (2013) proved that energy and food industry also play an important role in creating a healthy lifestyle.

\footnotetext{
${ }^{*}$ Corresponding author. Tel.: +60 167123422

E-mail address: kembara_pulau@outlook.com
}

ISSN: 2398-4287@ 2017. The Authors. Published for AMER ABRA by e-International Publishing House, Ltd., UK. This is an open access article under the CC BYNC-ND license (http://creativecommons.org/licenses/by-nc-nd/4.0/). Peer-review under responsibility of AMER (Association of Malaysian Environment-Behaviour Researchers), ABRA (Association of Behavioural Researchers on Asians) and CE-Bs (Centre for Environment-Behaviour Studies), Faculty of Architecture, Planning \& Surveying, Universiti Teknologi MARA, Malaysia.

DOI: http://dx.doi.org/10.21834/e-bpj.v2i5.691 
Besides, Todd, Mancino, \& Lin (2010) stated that there is a relationship between the consumption of food away from home and both diet quality and obesity. This is because food away from home normally contains high calories and high fat that may exacerbate the problem of obesity and the health problem as well (Yoon \& George, 2012; Espino et al., 2015; Todd et al., 2010). Vanderlee \& Hammond (2014) also supported the statement by saying food eaten away from homes such as fast-food and other restaurants can be associated with higher intakes of energy, fat and saturated fat, as well as lower intakes of fibre, calcium, fruit and vegetables.

Vyth et al. (2011) stated that a worksite cafeteria is a crucial place where people will be exposing to healthy food choices, and the food intake during lunch appears to contribute significantly to the consumption of this food.So, it is proven that restaurants are the utmost settings for interventions to improve the food environment (Valdivia Espino et al., 2015). This statement also supported by Khakzand \& Aghabozorgi (2015) where they agreed that the environmental condition does have a relationship with food choice. Therefore, in order to prevent obesity, Cheong, Kandiah, Chinna, Chan, \& Saad (2010) suggested to promote a healthy body weight at the worksite as it can reach large parts of the adult population from different social background and they normally spend most of their time at worksite (Maes et al., 2012). However, Thomas, Puig Ribera, Senye-Mir, \& Eves (2015) stated that there are some barriers at worksites that may limit the healthy food choices

In a study by Cecil \& Ldn (2014), the strategy to prevent health problem is by getting experts from many disciplines including nutritionists, physicians, policy-makers and public health professionals involve in this phase. A healthy cafeteria module can be a nutrition education tool to be used by cafeterias as nutrition education is defined as "any combination of educational strategies, accompanied by environmental supports, designed to facilitate voluntary adoption of food choices and other food- and nutrition-related behaviours conducive to health and well- being" (Contento, 2011). In fact, a guideline for a cafeteria had been made public by Malaysian Ministry of Health which is Garis Panduan Penilaian Pengiktirafan Kafeteria Sihat Edisi Kedua 2016. According to this guideline, a healthy cafeteria is defined as premise that provides, serves and sells food and drink that is nutritious, clean and safe to be consumed. Healthy Cafeteria should be located in an enclosed building that applies a good manufacturing practice as well as a healthy food principle.

However, the current guideline was not being fully implemented by the foodservice operator and the reason remain unclear. Therefore, a study to identify the factors of non-compliance foodservice operator is necessary to understand the phenomena. According to Gill, Stewart, Treasure, \& Chadwick, (2008), interview method is the most suitable method for qualitative study in providing a 'deeper' understanding of social phenomena as compared to quantitative methods. In this study, managers of the cafeteria, food handlers and cleaners were interviewed. The topics include attitude towards the food hygiene and safety, also knowledge about healthy food, hygiene and the safety of cafeteria, and the last aspect is the questions about their current practices in the cafeteria.

This study had come out with factors that associate with healthy cafeteria practice among cafeteria staff. The selected and useful points from the result will be used to develop a Healthy Cafeteria Module. This module can be used by cafeteria's operators as a nutrition education tool to prevent the problem of obesity and helps in increasing the health status of adults.

\subsection{Methods}

A total of 11 respondents were recruited in this study. Semi structured interview were conducted with managers $(n=3)$, food handlers $(n=5)$ and cleaners $(n=3)$. Semi-structured interviews have of some key questions that will help to define the areas to be explored (Gill et al., 2008). Face to face also interviewed was conducted. Coding such as [Food 1, Man 2 and Clean 3] is purely to maintain the anonymity of the managers, food handlers and cleaner. [Food] is for Food handlers, [Man] is for manager and [Clean] is for the cleaners. They were numbered accordingly such as [Man 1] for the first manager who had been interviewed. Then [Man 2] is the second manager who had been interviewed and same goes to the third manager and other samples.

\subsection{Sampling}

A purposive sampling strategy was used in this study focusing on staffs involve in the foodservice industry. The total respondents are eleven respondents including three full time managers, five full time food handlers and three full time cleaners. All of them were interviewed face-to-face. A manager, at least a food handler and a cleaner was the respondent for each of the cafeteria. Semistructured questions were used in this interview as it is more suitable for this research because it involves open ended questions that will give opportunities for the interviewer and respondent to elaborate more detail (Dixon, 2015; Hancock, 2006). On the other hand, qualitative research does not have a specific number of the samples as data was collected until it reached a saturation phase.

The inclusion criteria for the respondent are food handlers must be the one who handles food and according to Saad, Toh, \& Adil (2013), food handlers are the most important subject in determining and controlling the best practices of hygiene. A manager is the one who manages the café. A cleaner, involves in cleaning process at the cafeteria. The entire respondents must be working full time in the cafeteria. Besides that, the respondents who have chronic disease and not able to understand or speak Malay language fluently has been excluded in this research. Samples were chosen from 3 different cafeterias, 2 of them are in Shah Alam and the other cafeteria is in Sungai Buloh, Selangor.

\subsection{Interview protocol}

In order to govern the ethics of this project, a thorough review of the procedures and rationale of this study was very important. Before the interview take part, the respondents were informed about the study details as this can give an idea to the respondents to answer the questions. Besides, they are given assurance about the ethical principles such as guarantees that all the information given 
by them will be confidential and they have the right to privacy and refuse to answer certain questions if they feel uncomfortable to answer those questions. All interviews were tape recorded and transcribed verbatim afterwards, as this protects against bias and provides a permanent record of what was and was not said. Notes were also taken during the interview session. Permissions were sought from the respondents before the interview session start.

\subsection{Data analysis}

According to Smit (2002), data are transcribed before it is being analyse, meaning that texts from interviews, observational notes or memos are typed into word processing documents. ATLAS.ti version 7.0 was used as it will make the data analysis become easier especially for the writing process Lewis (2012). All the data that had been transcript were categorised by using key themes. All the other information was being sub into the suitable key themes and each of the themes had its own mind map that shows the connection between one respondent and another.

\subsection{Results}

\subsection{Profile of respondent}

The respondents' profile is shown in Table 1. The overall age range for all the respondents is around 23 years old to 61 years old with male respondent dominated the survey by $80 \%$ of male food handlers and $100 \%$ of male cleaners. However, female respondents dominated the manager position by $100 \%$. The education background of the respondents are secondary and tertiary level. All of the respondents had working experience from 1 to 20 years.

Table 1: Demographic data of the respondent.

\begin{tabular}{|c|c|c|c|c|c|}
\hline \multirow[t]{2}{*}{ Staff type } & \multirow[t]{2}{*}{ Age range } & \multicolumn{2}{|c|}{ Gender \% } & \multirow[t]{2}{*}{ Education level } & \multirow[t]{2}{*}{ Years of experiences } \\
\hline & & Male & Female & & \\
\hline Manager & $39-57$ & 0 & 100 & Tertiary & $1-20$ years \\
\hline Food handler & 23- 61 & 80 & 20 & Secondary & $1-20$ years \\
\hline Cleaner & 23-27 & 100 & 0 & Secondary & $1-20$ years \\
\hline
\end{tabular}

\subsection{The understanding of Healthy Cafeteria.}

All the cafeteria managers were interviewed defined a healthy cafeteria as a café that serve healthy choices of food. Three of them described the example of healthy food is vegetable: "...vegetables are a must, because it's important" [Man 1], "...example like salad" [Man 2] and "for example, healthy types of vegetables" [Man 3].

Besides, they said that the method of cooking will also define a cafeteria. A healthy cafeteria should reduce the usage of cooking oil in cooking process. One of the managers $(33 \%)$ claimed that not all the dishes have to use coconut milk as the ingredient: "...it is not necessary all the dishes should be cook using coconut milk" [Man 2] and she also believed that a healthy cafeteria should have a variety of food choices because it's good for health

The majority of the food handlers $(60 \%)$ defined a healthy cafeteria as a café that is clean and follow the hygienic practice: "...make sure ourselves are clean before entering the café" [Food 2], "In addition, cleanliness is a very important aspect in cafeteria" [Food 4] and "...a clean place" [Food 5].

Besides, two food handlers (40\%) had mentioned about food pyramid. They claimed that a healthy cafeteria should follow food pyramid: "like... that triangle diagram" [Food 1] and "...follow the triangle thing, what we need to eat the most and the less" [Food 3].

Majority of food handlers (80\%) indicated that a healthy cafeteria is also a cafeteria that serve healthy meals: "a healthy cafeteria has healthy food that serves fresh food" [Food 1], "...a place that serve healthy food" [Food 3], "the preparation of the food to the customer such as a balance meal" [Food 4] and "A healthy food" [Food 5].

A food handler $(20 \%)$ said that an example of ingredient that should be avoided in a healthy cafeteria is MSG: "...no MSG in cooking, this is very important." [Food 4].

Interviews with cleaners had come out with the result, most of them (67\%) define a healthy cafeteria is a café that is clean: "first, is the food hygiene... [Clean 1] and "...the cleanliness of the floor. In short, the café has to be clean" [Clean 2].

The other aspect of a healthy cafeteria is the food in the café itself. One of the cleaners (33\%) believed that the food serve in the café must be a healthy food: "...it serves healthy food such as fruits, less oily food as well as less sugar" [Clean 3]. In addition, another cleaner define a healthy cafeteria as a café that has a high quality of food: "the second aspect is the food quality" [Clean 1].

These finding shows, most of the respondents $(73 \%)$ define a healthy cafeteria as a café that serves healthy food and some of them (45\%) also understand that a healthy cafeteria should maintain its hygiene.

\subsection{Current practice in cafeteria}




\subsubsection{Food safety}

\subsubsection{Typhoid injection}

Almost $91 \%$ of the respondents claimed that they already had typhoid injections to ensure the food safety in their cafeteria. However, a respondent claimed that he had an injection to secure the food safety during the interview session but he was not sure the type of injection that he had received: "not sure" [Food 2]. In addition, all managers reported that it is compulsory for their workers to get typhoid injection: "every year, they must get an injection but I'm not sure what it's called" [Man 1], "yup, typhoid injection. It's a compulsory" [Man 2] and "typhoid is a must" [Man 3]. This result is slightly the same as a research done by Saad et al. (2013), that the more than $97 \%$ of the respondents had received typhoid immunization.

Four respondents $(36 \%)$ understand the purpose of getting typhoid injection. They believe that by having an injection, they will have a stronger antibody: "...If we are sick, typhoid will help in preventing the disease" [Food 1], "it will prevent us from any disease" [Food 3], "our antibody can last longer and stronger" [Food 4] and "...our antibody will become stronger and prevent our body from getting any viruses or bacteria infection" [Clean 3].

Many of the responses (55\%) indicated that they will receive typhoid injection every 3 years: " 3 years ,I already had the" [Food 1], "one injection in every 3 years" [Clean 1], "the lifetime for typhoid is 3 years before it get expired" [Man 2], "it can last for 3 years" [Food 4], "the expired for typhoid is 3 years" [Clean 2], and every 3 years" [Man 3]. In addition, only a respondent (9\%) indicated that he get typhoid injection every two years: "the best time to get typhoid injection is every 2 years " [Food 3]. Rest of the respondents did not mention about this.

\subsubsection{Food handling course}

All the responses reported that they already attended a food handling course. Only two of them (18\%) did claim that the course is compulsory for cafeteria staff to learn about food hygiene and food safety: "it's a compulsory condition in handling food"' [Food 1] and "it's a must to attend food handling course" [Man 3].

\subsubsection{Food availability and methods of cooking.}

Moreover, the interviews also revealed that their café serve varieties of Malay traditional dishes. Some of them (18\%) said that they serve 'Nasi lemak' for breakfast: "we serve 'nasi lemak' for breakfast..." [Food 5] and 'the menu is a typical menu. For breakfast we have 'nasi lemak',..." [Clean 3]. A manager claimed that western dishes are not the customer choices in his café: "we also serve western menu but it's not a customer preference." [Man 3].

Out of eleven respondents, 2 of them (18\%) claimed that in order to make a healthy menu, they reduced the amount of salt while preparing the foods: "For breakfast, I serve porridge and only use little salt "[Food 1] and "we reduce the use of salt to make the food become less salty" [Man 3]. However, only a respondent (9\%) misunderstood the purpose of reducing salt in dishes: "we don't use salt in dishes for diabetes people" [Food 2]

In addition, $18 \%$ of the respondents claimed that they don't use artificial food flavouring in their dishes: "no, we don't use food flavouring in our dishes..." [Man 1] and "we only used traditional way by using salt and sugar only and sometimes we blend anchovies to add in our dishes" [Food 5].

To investigate the example of healthy menu served, respondents were asked to explain about the example of healthy menu that they had prepared. 3 of them $(27 \%)$ had mentioned that vegetables is an example of healthy menu that they prepared at their cafeteria: "green vegetables is a must" [Man 1], "should be a lot of vegetables" [Food 3] and "such as..vegetables" [Man 3]. A respondent also said that they change the method of cooking of the food into a healthier way: "we grill food to reduce the use of cooking oil" [Man 3]. Besides, the use of frozen and instant food is also permitted in her café as said by a manager: "we don't use frozen food, we don't serve unhealthy food " [Man 3] and "instant...we don't prepare that" [Man 3].

\subsubsection{Sanitation and food hygiene}

Among eleven of respondents, five of them (45\%) indicated that they have to wear proper and clean uniform to ensure the food hygiene: "we have to wear gloves when holding anything" [Man A], "the complete uniform including the gloves and chef's hat" [Clean 2], "so, first. Uniform is very important. A proper uniform will also display the cafeteria" [Food 4], "another thing, uniform must always be clean" [Food 3] and "the uniform must always be clean as well as the personal hygiene" [Food 5].

In addition, two of the respondents (18\%) said that dish washers were used to clean all the dirty plate or other cooking utensils. Besides, one of the food handlers $(20 \%)$ did explain about the first in-first out system in their café to maintain the quality of their food: "we practice first in-first out system. So we keep all the new ingredients and we use the old ingredient "[Food 1].

Almost $40 \%$ of the food handlers did explain about avoiding cross contamination in receiving ingredients: "cross contamination such as inion and chicken" [Food 4] and "wet ingredients like chicken and meat, because this can cause cross-contamination" [Food 3].

\subsection{Challenges to implementing the healthy cafeteria.}

Most of the responses claimed that they have no problem in their café. However, to implement this healthy cafeteria module, there are certain problems. First, a food handler reported that he is having trouble in dealing and teaching the foreign workers to do work. He claimed that he has to hired foreign workers because their salary is cheaper compare to local worker: "The current problem is the foreign workers "[Food 1] and continue with "the first factor is because there is no local workers and second is the financial" [Food 1]. 
Another respondent also complain the kitchen's floor is slippery and the doors are not suitable, already broken and unsafe to use: "it's not a kitchen door and some are broken" [Clean 2] and "the floor is not suitable and slippery" [Clean 2]. Besides, five over eleven respondents claimed that they do not have any problem in term of the number of workers. However, the other six respondents did not mention about this problem.

A food handler $(20 \%)$ indicated that costing is a problem. He said that prices of the goods are increasing making food become costly: "...the price of goods are expensive" [Food 4]. In contrast, to 2 of the respondent claimed healthy menu could save cost and not necessary costly: "it depends on what we want to serve...not necessary all the healthy food is expensive" [Man 3] and "so, it's actually will save cost". [Clean 3].

Questions regarding kitchen equipment were also asked during the interview. Most of the responses said that they do not have this problem in their café and some responses said the other way: "we don't have the food warmer in our café." [Food 3] and "we should have food warmer as it can maintain the food temperature.'[Clean 2].

\subsection{Suggestions for developing the healthy cafeteria.}

Most of the $45 \%$ suggestions given by the respondent in order to develop a healthy cafeteria were by having printed materials such as poster, banner and template as a promotion for healthy eating: "we should put images that explain about healthy food "Food 3], "via poster or banting "[Man 3], "maybe we can make flyers and allocate posters at the entrance of the cafeteria or beside the counter, so that customer will aware of it'[Clean 3], "..we put more banner. Then we also put information about healthy food..." [Food 1], "we can give pamphlets that explain about healthy eating "[Food 1], and "put more stickers and poster...sticker from ministry of health, sticker about diet menu and attached it at the cafeteria walls"[Clean 1].

Besides, almost half the respondents suggest serving healthy menu at the cafeteria to promote healthy eating as some of them had already practiced it: "use the diet menu" [Clean 1], "we make a menu and categorised it into less salt, less sugar and less oil" [Man 2], "another thing, for the healthy food, choose the healthy menu" [Food 3], "all the menu in this café must be suitable and do not contain MSG. That's the most important thing" [Food 4] and "healthy food menu" [Clean 3].

Other than that, in term of the food safety, a respondent suggested to buy food warmer to maintain the food temperature. Apart from that, pest control was also being suggested to monitor the cleanliness of the kitchen: "make sure to monitor the entire cooking area to ensure the cleanliness after cooking or prepare the food" [Clean 3].

Next, a respondent gives an idea to make a campaign about healthy eating as it may help in creating awareness about healthy eating: "we make a campaign..." [Man 3]. On the other hand, a manager from other café shared about promotion strategy that her café used to do in promoting. They change their menu every three months so that the menu will be varieties. This strategy may also be used in a healthy cafeteria to promote healthy eating. Personal hygiene is also an important part in healthy cafeteria as claimed by a food handler: "cafeteria staff should always be in a healthy condition as well as keep their personal hygiene" [Food 4].

\subsection{Discussion}

European Food Safety Authority proved that it is important to practice food safety (EFSA, 2010) as evidence by $48.7 \%$ of foodborne diseases is associated with the catering or food service in 2010 and a study by Abdul-Mutalib et al. (2012) discovered that food handlers may be the leading of food contamination if they neglect a proper food handling practices in their premises. Mclntyre et al (2013) in his study stated that food handlers must be educate to prevent foodborne illness as it is the one of the main objective of the industry. In a research by Abdullah Sani \& Siow (2014) revealed that supervisors and management must support and give motivation to staff in order to make sure that the food safety training is a success. Besides, a latest study by Parry-Hanson Kunadu, Ofosu, Aboagye, \& Tano-Debrah, (2016) also support this statement by saying that the problem could be solved by training the food handlers in order to give them understanding about food safety.

This research showed that, all the respondents had attended the food handling course and taken typhoid injections. In order to prevent food contamination, food training on a regular basis is suggested by Abdullah Sani \& Siow (2014). Related to healthy cafeteria, there are some practice that they are practicing such as the preparation of the food in term of cooking methods and ingredients used in menu, the café's menu itself, and also the sanitation and hygiene part. A research done by Chen, Chi, Chu, Chen, \& Huang (2010) showed that people who cook normally have the knowledge about unhealthy ingredients but, they have to suit it with their culture. Addition to that, a study by He et al. (2011) had found out that Monosodium Glutamate (MSG) consumption is associated to the risk of becoming overweight with adjustment for baseline BMI. In a research by Baş, Şafak Ersun, \& Kivanç (2006), revealed that food handlers may transmit pathogens passively from a contaminated source, for example, from raw poultry to a food such as cold cooked meat that is to be eaten without further heating. Besides, in another research done by Saad, See, Abdullah, \& Nor (2013), also agreed that activities such as, cutting or slicing of cooked food, adding garnishes can potentially reintroduce the food to the harmful organisms. These statements support the comments given by food handlers in previous paragraph as cafeteria workers must wear proper and clean uniform in order to prevent any transmit of pathogens.

Most of respondents believed that they have to wear proper and clean uniform during working hour to maintain a healthy and clean environment. This is because, Hygiene is very important as most of the main causes of foodborne illness outbreaks is due to worker illness and poor food handling practices (Mclntyre, Vallaster, Wilcott, Henderson, \& Kosatsky, 2013). As reported by (WHO, 2014), it is estimated that $30 \%$ of population in industrialized countries suffering from foodborne illness annually due to foodborne diseases that cause majority of mortality and morbidity worldwide. This shows that, they actually understand about the importance of practising food safety in their café. However, a research done by Seaman \& Eves (2010) revealed that most food industry managers knew about 
their responsibilities to provide training to their food handlers. However, they do not have the skills, resources or systems in place to provide appropriate food hygiene training or post training support for their food handlers. These were the major challenges faced by managers.

However, challenges faced by respondents are foreign workers, unsuitable kitchen facilities and equipment and also in term of cost. Woh, Thong, Behnke, Lewis, \& Mohd Zain (2016), conclude that the intake of foreign workers keep increasing by years because Malaysian food service industry keep growing by years and same goes to the demand of manpower. As for problem associated with foreign workers, a study by Woh et al. (2016), had found out that, foreign food handlers with better understanding of Malay or English language and/or had longer employment or length of residence in Malaysia tend to acquire knowledge better. So, the solution to this problem is first, to provide language education or specifically, Malay or English classes for them.

As mentioned in the previous paragraph, the unsuitable kitchen facilities and cooking equipment are also the challenges facing by cafeteria operator to create a healthy cafeteria. George et al., (2015), supported that one of the barriers to create a healthy cafeteria is the cafeteria does not have proper kitchen equipment. A respondent had mentioned about the door used in their kitchen is not suitable. According to Jali, Ghani, \& Nor (2016), in avoiding the entry of insects and maintaining a good airways pressure to maintain cleanliness in food premise, a suitable door should be used which is self-closing doors. Thus, a cafeteria must follow the Good Manufacturing Practices (GMP) because it is one way to achieve a high standard of food quality (Rodrigues, 2016). However, food handlers should have a proper training in managing kitchen facilities and equipment because this may improve or maintain the standard of sanitation environmental condition (Jeon, Park, Jang, Choi, \& Hong, 2015).

Besides, healthy food is often perceived as an expensive and time consuming as claimed by a respondent. This is because with the help of technology, normally unhealthy processed food is way cheaper than a healthy food as claimed by Wiggins et al., (2015) causing low income people to consume more unhealthy food. Contrary, McDermott \& Stephens, (2010) had found out that low-cost healthy diet is more cost-effective for low income families. However, low cost nutritional food may be less prefer by certain people because it is low in palatability and variety (Lin \& Scott, 2012).

Method of cooking and food availability play an important role in determining a person's health status. However, food should taste good as well as the food quality is one of the important factor for customer satisfaction and loyalty (Voon, 2012). One of the reason for obesity is the unhealthy diet such as regularly consume fast food as todays, the food is easy to get (Abdullah, Mokhtar, Bakar, \& AlKubaisy, 2015). So, healthy food availability is also important in creating a healthy environment in cafeteria. Adedeji \& John (2015), claim that food available at or near workplaces normally are convenient, low in cost and sells well.

As for the method of cooking, Lessa, Zulueta, Esteve, \& Frigola, (2017) showed that a quality of a menu will not change its nutritional profiles if the food handlers have scientific knowledge in cooking methods. Meaning that, even though the method of cooking is changed and food handlers have knowledges about the nutritional values, it can maintain the quality of the food. Besides, a study at worksite cafeterias in South Korea has revealed that most of the respondents in this study usually consume sodium-reduced meal with 49\% respondents (Lee \& Park, 2015). Alonso (2014), had found out that culture and religion affect food preferences. This statement well explained the type of menu served at all three cafeterias as their main menu is Malay food. Thus, the method of cooking that is being practice depends on the menu in cafeteria.

Besides, one of the limitations in the previous study by Thorndike, Riis, Sonnenberg, \& Levy (2014) about food labelling is people may become bored in making healthy food choices and revert back to their original unhealthy choices. In term of printed materials, almost half of the respondent suggested to hang printed materials such as banner, poster, pamphlets and Banting at the strategic area in the café in order to create a healthy eating environment. Decorating a cafeteria can also create a healthy environment as stated by El-zeiny (2013), in his research that workplace interior design can improve the quality of life and aesthetically appealing. Apart from the suggestions, menu labelling can also be include in this study as a study by Roberto, Schwartz, \& Brownell (2009) had discovered that menu labelling may have effects on food choices and health status. Other than that, choices logo is impactful for people who want to make a healthy choice during lunch (Vyth et al., 2011) and according to Sonnenberg et al. (2013), traffic light food labels initiate customer to make a healthier choice and increase the awareness on making a healthy food choices at the point-of-purchase as well. Besides, result from a research by Din, Salehuddin, Zahari, \& Shariff (2011), reveal that calories, protein, fat and dietary fibre which is the common highlighted nutrients in food retail products were the minimum desired information in the restaurant menu. Lots of research studies agreed that showing nutritional information on the menu will help customers making healthier eating choices (Din et al., 2011). A studied by Norrina Din, Zahari, Othman, \& Abas (2012), also reveal that the nutrient contents that were being observed by customers are cholesterol, salt, sugar and fat, and the used of added seasoning in restaurant menu items.

A research stated that in order to encourage consumption of healthy food such as fruits and vegetables, healthy eating advertisement is an relevant action (Wang \& Kaiser, n.d.). Apart from this, nutrition education among workers is also very crucial. In a research by Rockett et al. (2005) found out that nutrition education on the importance of a well-balanced diet may help in promoting adolescent weight maintenance. This strategy may also be applied to cafeteria workers.

The respondents also suggested that healthy menus should be served in the café as awareness campaign of healthy eating environment. In a research done by Mansor \& Harun (2014), they have discussed about campaigns and programmes that had been done by Malaysian government and also by others private companies in order to create health awareness among Malaysian. Besides, recycling campaign should also be done by cafeteria operators as apart from helping in saving the environment, it actually help in generating income (Singhirunnusorn, Donlakorn, \& Kaewhanin, 2012). Othman \& Yuhaniz (2012) stated that waste reduction and recycling activities is an important step in achieving a healthy life style and also protecting our environment. They also agreed that recycling is an energy saving action as the process is simple, less pollution and producing new things. 
You, Zhang, Davy, Carlson, \& Lin (2009) claimed that in order to achieved better diet, time availability, food accessibility, and cooking skills must be considered as well. This support the statement of the respondent about serving healthy menu in the café can create a healthy eating environment. In addition, suitable kitchen equipment also should be added in order to maintain the freshness of the foods and to avoid food spoilage. Besides, Condrasky \& Hegler, (2010) suggest to improve healthy cooking technique by enhancing culinary nutrition concepts in order to support eating practices that will improve the health status for the nation.

Cafeteria is a place for working people to have their meal when eating out, it's a perfect place to run all the suitable suggestions by respondents. This statement can be supported by a previous research by Luckhaupt, Cohen, Li, \& Calvert, (2014) in which they claimed that workplace can be considered as a place for obesity intervention along with collaboration from public health professionals and the employers.

\subsection{Practical Limitation of the study}

The limitations of exploratory or qualitative research is that we may become bias in analyse the date or during interview compare to quantitative research that the answer is based on the choices given in the questionnaires. However, different respondents gave different opinions and suggestions in certain questions and some of them support the other respondents answer though they are not from the same cafeteria. Some of the points given by the respondents may not be useful for our study. On the other hand, in quantitative study, we will get a direct answer form the respondents. Apart from that, some of the respondents do not want to participate in this study, limiting the data for this study. Some respondents gave less cooperation making the data collection become difficult and not detail. Moreover, a few audio recorded was not very clear as some of the respondents were not interviewed in a proper place causing noises in the audio. This situation leads to a complication when it comes to the transcription phase. Same goes to the video recording, where some of the videos were not positioned in a right angle making a difficulty in observing the expressions of the respondents.

\subsection{Conclusion}

This study revealed that the right understanding, knowledge, practices, and many ways of healthy eating promotions will create a healthy eating environment among workers and healthy practices among cafeteria staff. However, there are several limitations experienced by the foodservice operators that need to be taken into consideration. Thus, Malaysian government may want to take a look on this issues and find the best solutions to provide a healthy eating environment to the workers. It is suggested to conduct another study that explore the needs of foodservice operators in a larger scale samples.

\section{Acknowledgement}

This research was funded by the Universiti Teknologi MARA under grant no: 600-RMI/ DANA 5/3/LESTARI (48/2015). Thank you to al researchers that involve in this study.

\section{References.}

Abdullah, N. N., Mokhtar, M. M., Bakar, M. H. A., \& Al-Kubaisy, W. (2015). Trend on Fast Food Consumption in Relation to Obesity among Selangor Urban Community. Procedia - Social and Behavioral Sciences, 202(December 2014), 505-513. http://doi.org/http://dx.doi.org/10.1016/j.sbspro.2015.08.189

Abdul-Mutalib, N. A., Abdul-Rashid, M. F., Mustafa, S., Amin-Nordin, S., Hamat, R. A., \& Osman, M. (2012). Knowledge, attitude and practices regarding food hygiene and sanitation of food handlers in Kuala Pilah, Malaysia. Food Control, 27(2), 289-293. http://doi.org/10.1016/j.foodcont.2012.04.001

Adedeji, O. A., \& John, U. I. (2015). Food Environment and Unhealthy Eating Habits among Adolescents in Tertiary Institutions. American International Journal of Research in Humanities, Arts and Social Sciences, 9(1), 72-77.

Alonso, E. B. (2014). The impact of culture , religion and traditional knowledge on food and nutrition security in developing countries, (30), 79.

Baş, M., Safak Ersun, A., \& Kivanç, G. (2006). The evaluation of food hygiene knowledge, attitudes, and practices of food handlers' in food businesses in Turkey. Food Control, 17(4), 317-322. http://doi.org/10.1016/j.foodcont.2004.11.006

Cecil, M., \& Ldn, R. D. (2014). Managing and Preventing Obesity: Behavioural Factors and Dietary Interventions. Journal of Nutrition Education and Behavior, 48(4), 372. http://doi.org/10.1016/j.jneb.2015.12.005

Cheong, S. M., Kandiah, M., Chinna, K., Chan, Y. M., \& Saad, H. A. (2010). Prevalence of obesity and factors associated with it in a worksite setting in Malaysia. Journal of Community Health, 35(6), 698-705. http://doi.org/10.1007/s10900-010-9274-1

Condrasky, M. D., \& Hegler, M. (2010). How Culinary Nutrition Can Save the Health of a Nation. Journal of Extension, 48(2), 1-6. Retrieved from http://www.joe.org/joe/2010april/comm1.php

Contento, I. R. (2008). Nutrition education: Linking research, theory, and practice. Asia Pacific Journal of Clinical Nutrition, 17(SUPPL. 1), 176-179.

Davey, T. M., Allotey, P., \& Reidpath, D. D. (2013). Is obesity an ineluctable consequence of development? A case study of Malaysia. Public Health, 127(12), 1057- 
1062. http://doi.org/10.1016/j.puhe.2013.09.008

Din, N., Salehuddin, M., Zahari, M., \& Shariff, S. M. (n.d.). Nutritional Labelling in Malaysian Full, 51-59.

Din, N., Zahari, M. S. M., Othman, C. N., \& Abas, R. (2012). Restaurant Operator's Receptiveness towards Providing Nutritional Information on Menu. Procedia - Social and Behavioral Sciences, 50(July), 699-709. http://doi.org/10.1016/j.sbspro.2012.08.073

Dixon, C. S. (2015). Interviewing adolescent females in qualitative research. Acta Polytechnica Hungarica, 12(8), $2067-2077$.

EFSA (European Food Safety Authority), 2010. Application of systematic review methodology to food and feed safety assessments to support decision making. The EFSA Journal (2010), 8(5):1637, pp. 1-90.

El-zeiny, R. M. A. (2013). Interior Design of Workplace and Performance Relationship : Private Sector Corporations in Egypt. Asian Journal of Environment-Behaviour Studies, 4(11), 49-61. http://doi.org/10.1016/j.sbspro.2012.02.145

Espino, J. N. V., Guerrero, N., Rhoads, N., Simon, N., Escaron, A. L., Meinen, A., ... Martinez-donate, A. P. (2015). Community-Based Restaurant Interventions to Promote Healthy Eating : A Systematic Review, 1-21.

George, A., Berner, M., Dunning, R., Allison, G. S., Ammons, D. N., Anderson, A. M., ... Markham, J. M. (2015). North Carolina Public School Kitchen Capacity Study : Healthy Foods, Farms, and Kids, (July). Retrieved from https://www.sog.unc.edu/publications/reports/north-carolina-public-school-kitchen-capacity-study-healthyfoods-farms-and-kids

Gill, P., Stewart, K., Treasure, E., \& Chadwick, B. (2008). Methods of data collection in qualitative research: interviews and focus groups. British Dental Journal, 204(6) 291-295. http://doi.org/10.1038/bdj.2008.192

Jali, M. B., Ghani, M. A., \& Nor, N. (2016). A cE - Bs2016Taipei The Confusion of Design and Facilities in Good Manufacturing Practice Requirements among Industries in Malaysia, (April), 9-10.

Jan Mohamed, H. J. B., Yap, R. W. K., Loy, S. L., Norris, S. A., Biesma, R., \& Aagaard-Hansen, J. (2015). Prevalence and Determinants of Overweight, Obesity, and Type 2 Diabetes Mellitus in Adults in Malaysia. Asia-Pacific Journal of Public Health / Asia-Pacific Academic Consortium for Public Health, 27(2), $123-135$. http://doi.org/10.1177/1010539514562447

Jeon, M.-S., Park, S.-J., Jang, H.-J., Choi, Y.-S., \& Hong, W. (2015). Evaluation of sanitation knowledge and practices of restaurant kitchen staff in South Korea. British Food Journal, 117(1), 62-77. http://doi.org/10.1108/BFJ-08-2013-0209

Khakzand, M., \& Aghabozorgi, K. (2015). Achievement to Environmental Components of Educational Spaces for Iranian Trainable Children with Intellectual Disability Procedia - Social and Behavioral Sciences, 201(February), 9-18. http://doi.org/10.1016/j.sbspro.2015.08.113

Kimokoti, R. W., \& Millen, B. E. (2011). Diet, the Global Obesity Epidemic, and Prevention. Journal of the American Dietetic Association, 111(8), 1137-1140. http://doi.org/10.1016/j.jada.2011.05.016

Lee, J., \& Park, S. (2015). Consumer attitudes , barriers , and meal satisfaction associated with sodium-reduced meal intake at worksite cafeterias, 9(6), 644-649. http://doi.org/10.4162/nrp.2015.9.6.644

Lessa, K., Zulueta, A., Esteve, M. J., \& Frigola, A. (2017). Study of consumer perception of healthy menus at restaurants. Food Quality and Preference, 55, 102-106. http://doi.org/10.1016/j.foodqual.2016.05.007

Lewis, J. K. (2012). Using ATLAS.ti to facilitate data analysis for a systematic review of leadership competencies in the completion of a doctoral dissertation, 1-14.

Lin, G. G., \& Scott, J. G. (2012). NIH Public Access, 100(2), 130-134. http://doi.org/10.1016/j.pestbp.2011.02.012.Investigations

Luckhaupt, S. E., Cohen, M. A., Li, J., \& Calvert, G. M. (2014). Prevalence of obesity among U.S. workers and associations with occupational factors. American Journal of Preventive Medicine, 46(3), 237-248. http://doi.org/10.1016/j.amepre.2013.11.002

Maes, L., Van Cauwenberghe, E., Van Lippevelde, W., Spittaels, H., De Pauw, E., Oppert, J. M., ... De Bourdeaudhuij, I. (2012). Effectiveness of workplace interventions in Europe promoting healthy eating: A systematic review. European Journal of Public Health, 22(5), 677-683. http://doi.org/10.1093/eurpub/ckr098

Majid, H. A. M. A., Danis, A., Sharoni, S. K. A., \& Khalid, M. (2015). A icE-Bs2015Barcelona Environmental Mapping Framework and Childhood Obesity in Selangor ,.

Mansor, M., \& Harun, N. Z. (2014). Health Issues and Awareness, and the Significant of Green Space for Health Promotion in Malaysia. Procedia - Social and Behavioral Sciences, 153, 209-220. http://doi.org/10.1016/j.sbspro.2014.10.055

McDermott, A. J., \& Stephens, M. B. (2010). Cost of eating: Whole foods versus convenience foods in a low-income model. Family Medicine, 42(4), $280-284$.

Mclntyre, L., Vallaster, L., Wilcott, L., Henderson, S. B., \& Kosatsky, T. (2013). Evaluation of food safety knowledge, attitudes and self-reported hand washing practices in FOODSAFE trained and untrained food handlers in British Columbia, Canada. Food Control. http://doi.org/10.1016/j.foodcont.2012.06.034

Othman, A. R., \& Yuhaniz, M. (2012). Recycle of Domestic Waste among Terrace House Residents in Shah Alam. Procedia - Social and Behavioral Sciences, 50(July), 884-898. http://doi.org/10.1016/j.sbspro.2012.08.090

Roberto, C. A., Schwartz, M. B., \& Brownell, K. D. (2009). Rationale and Evidence for Menu-Labeling Legislation. American Journal of Preventive Medicine, 37(6), 546551. http://doi.org/10.1016/j.amepre.2009.07.015

Rockett, H. R., Field, A. E., Colditz, G. A., Gillman Elsie M Taveras, M. W., Berkey, C. S., Rifas-Shiman, S. L., ... Gillman, M. W. (2005). Index and Diet Quality in Older Children and Adolescents Association of Consumption of Fried Food Away From Home With Body Mass Association of Consumption of Fried Food Away From Home With Body Mass Index and Diet Quality in Older Children and Adolescents. Pediatrics, 116(4). http://doi.org/10.1542/peds.2004-2732 
Rodrigues, F. M. (2016). Importance of Quality Management in the Processors of Fruit and Vegetable Industries, 9359(2), 6-12.

Saad, M., See, T. P., Abdullah, M. F. F., \& Nor, N. M. (2013). Use of Rapid Microbial Kits for Regular Monitoring of Food-contact Surfaces towards Hygiene Practices. Procedia - Social and Behavioral Sciences, 105, 273-283. http://doi.org/10.1016/.sbspro.2013.11.029

Saad, M., Toh, P. S., \& Adil, M. A. M. (2013). Hygiene practices of food handlers at Malaysian Government Institutions Training Centers. Procedia - Social and Behavioral Sciences, 85, 118-127. http://doi.org/10.1016/j.sbspro.2013.08.344

Seaman, P., \& Eves, A. (2010). Perceptions of hygiene training amongst food handlers, managers and training providers - A qualitative study. Food Control, 21(7), 1037-1041. http://doi.org/10.1016/j.foodcont.2009.12.024

Singhirunnusorn, W., Donlakorn, K., \& Kaewhanin, W. (2012). Household Recycling Behaviours and Attitudes toward Waste Bank Project: Mahasarakham Municipality. Journal of Asian Behavioral Studies, 2(6), 35-47. http://doi.org/10.1016/j.sbspro.2012.03.075

Smit, B. (2002). Atlas.ti for qualitative data analysis. Perspectives in Education, 20(September), 65-76.

Sonnenberg, L., Gelsomin, E., Levy, D. E., Riis, J., Barraclough, S., \& Thorndike, A. N. (2013). A traffic light food labeling intervention increases consumer awareness of health and healthy choices at the point-of-purchase. Preventive Medicine, 57(4), 253-257. http://doi.org/10.1016/.ypmed.2013.07.001

Strasser, B. (2013). Physical activity in obesity and metabolic syndrome. Annals of the New York Academy of Sciences, 1281(1), 141-159. http://doi.org/10.1111/j.1749-6632.2012.06785.x

Thomas, E. L., Puig Ribera, A., Senye-Mir, A., \& Eves, F. F. (2015). Promoting Healthy Choices in Workplace Cafeterias: A Qualitative Study. Journal of Nutrition Education and Behavior, 48(2), 138-145.e1. http://doi.org/10.1016/j.jneb.2015.11.001

Thorndike, A. N., Riis, J., Sonnenberg, L. M., \& Levy, D. E. (2014). Traffic-light labels and choice architecture: Promoting healthy food choices. American Journal of Preventive Medicine, 46(2), 143-149. http://doi.org/10.1016/j.amepre.2013.10.002

Todd, J. E., Mancino, L., \& Lin, B.-H. (2010). The Impact of Food Away from Home on Adult Diet Quality. SSRN eLibrary, (90). Retrieved from http://papers.ssrn.com/sol3/papers.cfm?abstract_id $=1557129$

Valdivia Espino, J. N., Guerrero, N., Rhoads, N., Simon, N.-J., Escaron, A. L., Meinen, A., ... Martinez-Donate, A. P. (2015). Community-based restaurant interventions to promote healthy eating: a systematic review. Preventing Chronic Disease, 12, E78. http://doi.org/10.5888/pcd12.140455

Vanderlee, L., \& Hammond, D. (2014). Does nutrition information on menus impact food choice? Comparisons across two hospital cafeterias. Public Health Nutrition, 17(6), 1393-402. http://doi.org/10.1017/S136898001300164X

Voon, B. H. (2012). Role of Service Environment for Restaurants: The Youth Customers' Perspective. Procedia - Social and Behavioral Sciences, 38(December 2010), 388-395. http://doi.org/10.1016/j.sbspro.2012.03.361

Vyth, E. L., Steenhuis, I. H. M., Heymans, M. W., Roodenburg, A. J. C., Brug, J., \& Seidell, J. C. (2011). Influence of Placement of a Nutrition Logo on Cafeteria Menu Items on Lunchtime Food Choices at Dutch Work Sites. Journal of the American Dietetic Association, 111(1), 131-136. http://doi.org/10.1016/j.jada.2010.10.003

Wang, R., \& Kaiser, H. M. (n.d.). Does Advertising Content Matter? Impacts of Healthy Eating and Anti-Obesity Advertising on Willingness-to-Pay by Consumer Body Mass Index, (August 2015), 1-41.

Wiggins, S., Keats, S., Han, E., Shimokawa, S., Alberto, J., Hernández, V., \& Claro, R. M. (2015). The Rising Cost of a Healthy Diet, (May), 1-64. Retrieved from http://www.odi.org/sites/odi.org.uk/files/odi-assets/publications-opinion-files/9580.pdf

Woh, P. Y., Thong, K. L., Behnke, J. M., Lewis, J. W., \& Mohd Zain, S. N. (2016). Evaluation of basic knowledge on food safety and food handling practices amongst migrant food handlers in Peninsular Malaysia. Food Control, 70, 64-73. http://doi.org/10.1016/j.foodcont.2016.05.033

Wolfenden, L., Jones, J., Finch, M., Rj, W., SI, Y., Ej, S., ... Cm, W. (2015). Strategies to improve the implementation of healthy eating , physical activity and obesity prevention policies , practices or programmes within childcare services ( Protocol ). Cochrane Database of Systematic Reviews, (7). http://doi.org/10.1002/14651858.CD011779

World Health Organization. (2014). Global Health Observatory (GHO) Mortality and Global Health estimate. Downloaded from http://apps.who.int/ gho/data/view.wrapper.MGHEMORTCAUSE10- 2012?lang=en\&menu=hide on 8/9/2014

Yoon, H. J., \& George, T. (2012). Nutritional information disclosure on the menu: Focusing on the roles of menu context, nutritional knowledge and motivation. International Journal of Hospitality Management, 31(4), 1187-1194. http://doi.org/10.1016/.i.jhm.2012.02.006

You, W., Zhang, G., Davy, B. M., Carlson, A., \& Lin, B.-H. H. (2009). Food consumed away from home can be a part of a healthy and affordable diet. Journal of Nutrition, 139, 1994-19999. http://doi.org/10.1016/S1096-7508(99)80028-7 